\title{
Correction to: Narratology Beyond the Human: Self-Narratives and Inter-Species Identities
}

\author{
David Herman
}

\section{Correction to:}

\section{S. McHugh et al. (eds.), The Palgrave Handbook of Animals and Literature, Palgrave Studies in Animals and Literature, https://doi.org/10.1007/978-3-030-39773-9_4}

The original version of this chapter was revised as there was an error in the abstract and the below given abstract was updated.

New text:

This chapter uses two works-Paula Fox's novel Desperate Characters (1970) and Alice Munro's short story “Boys and Girls” (1964)to consider how ideas from narrative studies can both inform and be informed by research on humananimal relationships. Although they employ very different narrative designs, both Fox and Munro use the resources of fiction to model how stories of the selfwhat social psychologists call "self-narratives"-need to be reframed within a widened, cross-species conception of self-other relations. The two case studies thus suggest how any number of narrational modes can be used to explore the possibilities and limitations of self-narratives in a more-than-human world.

The updated versions of this chapter can be found at https://doi.org/10.1007/978-3-030-39773-9_4

(C) The Author(s), under exclusive license to Springer Nature Switzerland AG 2021 